\title{
КРІЗЬ ПРИЗМУ ІМАГОЛОГІї: УКРАЇНСЬКО-ПОЛЬСЬКІ ВІДНОСИНИ В УКРАЇНСЬКОМУ ЛІТЕРАТУРНО-КРИТИЧНОМУ ДИСКУРСІ КІНЦЯ ХІХ - ПОЧАТКУ ХХ СТОЛІТТЯ
}

\author{
ГАЛИНА КОРБИЧ \\ Університет імені Адама Міцкевича, Познань - Польща \\ PRZEZ PRYZMAT IMAGOLOGII: STOSUNKI UKRAIŃSKO-POLSKIE \\ W UKRAIŃSKIM LITERACKO-KRYTYCZNYM DYSKURSIE \\ KOŃCA XIX — POCZĄTKU XX WIEKU
}

HALINA KORBICZ

Uniwersytet imienia Adama Mickiewicza w Poznaniu, Poznań — Polska

STRESZCZENIE. W artykule na materiale literacko-krytycznych wypowiedzi autorów ukraińskich końca XIX — początku XX wieku, m. in. Iwana Franki, Mykoły Jewszana, Dmytra Doncowa oraz innych, próbie analizy poddana została recepcja Polski rozpatrywanej jako podstawa stosunków polsko-ukraińskich. Rozpatrywana jest reakcja na w/w jako na złożoną konstrukcję dyskursywną, w której odnotowany został ruch poszczególnych elementów składowych, spowodowany kształtowaniem się nacji ukraińskiej.

\author{
UKRAINIAN-POLISH RELATIONS \\ IN UKRAINIAN LITERATURE DISCOURSE \\ OF THE END OF THE XIX ${ }^{\text {th }}-$ BEGINNING OF THE $X^{\text {th }}$ CENTURY
}

\section{HALINA KORBICZ \\ Adam Mickiewicz University in Poznań, Poznań — Poland}

ABSRACT. The article focuses on the perception of Poland as the basis of Ukrainian-Polish relations issued by literary critical reports made by the Ukrainian authors in the XIX ${ }^{\text {th }}$ - beginning of the $\mathrm{XX}^{\text {th }}$ century, such as I. Franko, M. Evshan, D. Dontsov, and the others. A certain reaction caused by Ukrainian national formation has been observed.

$\mathrm{I}$

нтерпретовані в цій статті літературно-критичні розвідки, що на зламі XIX i XX ст. засвідчили реакцію українських науковців на польську літературу

(а через неї, очевидно, й на весь дискурс українсько-польських суспільнокультурних стосунків), українським літературознавцям переважно відомі. Їхнє наукове осмислення здійснювалося насамперед в аспекті компаративістики шляхом зіставлення й порівняння, що закладало принцип рівноправності, а то й стверджувало рівновеликість обох сторін — польської й української (йдеться про дослідження Григорія Вервеса, Юлії Булаховської, Ростислава Радишевського, Володимира Моренця, Сергія Яковенка).

Проте українським дослідникам у той час власне й доводилося виборювати рівність позицій та відповідну паритетність у стосунках із сильним сусідом і тим самим утверджувати українську суб'єктність, доводити національну й культурну ідентичність. Здійснювалося це не лише шляхом прямих протидій - 
протиставлень і полеміки, а й — чи не більшою мірою - у ході обсервацій як реакції на „іншого”, репрезентацією „іншого”. Такі підходи відображають розмаїття уявлень, що свідчить не лише про того, кого сприймають, а й про того, хто сприймає ${ }^{1}$.

Отже, не виходячи за межі компаративістичних досліджень, можна проаналізувати відомий літературний матеріал крізь засади імагологічних досліджень, що вивчають міжнаціональні взаємоуявлення, осмислені крізь призму літературознавства. Тим паче, що ці наукові студії вже доводять свою продуктивність, озброюючи дослідників теоретичними й методологічними концепціями, що дає змогу переглянути як окремі аспекти, так і спадщину кожного письменника загалом, зокрема й українського (в Україні це праці Дмитра Наливайка, Марка Павлишина, Василя Будного, Володимира Орєхова, Павла Рудякова).

Процес українського націєтворення, що поступово розгортався впродовж XIX ст., набуває потужної активізації наприкінці XIX і на початку XX століть. Національні критерії, що в минулому мали неясний і мінливий характер, замінюються критеріями національного самовизначення й самоорієнтації. Саме вони $є$ ключем до виявлення й осмислення національної ідентичності ${ }^{2}$. У вигляді багатовимірної концепції оформлюється українська національна ідентичність у художній літературі та літературно-критичних працях. Як динамічна галузь українського суспільно-культурного життя літературна критика стала тією сферою, в якій створюється модель нової модерної культури, що приходить на зміну так званій ізоляціоністсько-народницькій. Стратегія побудови нової моделі заснована на пізнавально-орієнтаційних та оцінювальних принципах, у яких важливу роль відіграють засадничі проблеми імагології — категорія ідентичності Я або колективних ідентичностей в спектрі їх широкого виміру ${ }^{3}$.

Про характер українсько-польських стосунків свідчить українська рецепція Польщі. Багатоаспектно висвітлюючи історичний досвід, вона є неоднозначною: залежно від історичних процесів, соціально-культурних ситуацій відбувається актуалізація одних та нейтралізація інших чинників, з'являються нові факти. Унаслідок цього процесу образ / імідж Польщі набуває вигляду складної дискурсивної конструкції з багатовимірними складовими. Українські письменники різних часів чимало писали про сусідів, образ Польщі й поляків можна вважати одним із найбільш поширених в українському духовному просторі та соціокультурній свідомості. У ньому зберігаються константні уявлення, але й виникають нові, зумовлені об'єктивно-історичними й суб'єктивнопсихологічними чинниками. Така складна й різноманітна структура сприйняття Польщі й поляків виникла внаслідок безпосередніх контактів, коли значна частина земель не лише Східної, а й Центральної Свропи була місцем їхнього спільного проживання. Однак попри фізичну близькість, ставлення українців до поляків у національному відношенні ніколи не було позначене презумпцією двоїстості: поляка однозначно трактували як „чужого”, „іншого” за етнічною, культурною, релігійною, мовною приналежністю.

Важливим елементом етнокультурного образу поляків, засадничого в імагології ${ }^{4}$ структурним ядром його рецепції став чинник аристократичності

${ }^{1}$ Див.: Imagologia, [w:] Źródło elektroniczne: http://translate.googleusercontent.com/translate_ $\mathrm{c} ? \mathrm{hl}=\mathrm{pl} \& \mathrm{sl}=\mathrm{it} \& \mathrm{u}=\mathrm{http}: / /$ it.wikipedia $(2010.07 .14)$.

2 Див. докладніше: Е.С міт, Нащіональна ідентичність, Київ 1994, с. 26.

3 Д. Налив ийко, Літературна імагологія: предмет і стратегії, [в:] його ж, Теорія літератури й компаративістика, Київ 2006, с. 94.

${ }^{4}$ Див. там само. 
як вродженої, так і набутої риси національного характеру (це асоціювалося також із гордовитістю, пихатістю, зарозумілістю), що у взаєминах з українцями виявлялося як умотивоване в польському дискурсі “почуття вищості”, права панування над спільним територіальним простором тощо. Аристократичність, або шляхетність як характерна риса поляків була зафіксована в колективних уявленнях українців, яку трактували зазвичай іронічно, негативно. Акцентування уваги на „шляхетності” визначало його ієрархічну роль у художній репрезентації образу поляка, що переходило в українську свідомість із літературної творчості Тараса Шевченка, Івана Франка, Лесі Українки, Михайла Старицького, Леся Мартовича та інших письменників XIX й початку XX ст.; ця тенденція зафіксована і в текстах попередніх століть ${ }^{5}$. Усталене переконання у зверхності поляків, що базувалося на емпіричному досвіді українських авторів, підсилювало стереотипне уявлення.

Проте, як відомо, в основі виникнення стереотипів лежать не лише пізнавальні властивості людського розуму, а й насамперед соціально-історичні зумовленості. У цьому разі на створення уявлень (і стереотипних, і загалом імагологічних) визначальний вплив мали чинники етносоціологічного характеру. За спостереженнями істориків (Романа Шпорлюка, Даніеля Бовуа, Богдана Гудя), після падіння Речі Посполитої у XVIII ст. поляки зберігали своє панівне становище не лише у Східній Галичині, що відійшла до Австрії, а й на теренах Київщини, Волині, Поділля, що опинилися під владою Російської імперії6.

Отже, образ українсько-польського „співжиття” складався з українських низів та польської суспільної верхівки. А колективний образ поляка формувався не лише на етнічній основі - $з$ іманентних рис національної вдачі, а й з огляду на колоніальну практику. 3 цього приводу зазначимо, що імагологія як інтердисциплінарна наука взаємодіє з різними науковими дисциплінами (етнологією, культурологією, соціологією та ін.), але в заявленій у цій науковій розвідці темі найбільший зв'язок вона має з постколоніальними студіями. Визнання факту, що „вища” позиція традиційно належить полякам, спонукало до захисту нижчої верстви, що привело до виникнення в них етнозахисної позиції і вимагало реалізації соціально та національно-культурної функції, яку стосовно своїх краян здійснювали українська художня й критична література. Що ж до останньої, то наприкінці XIX ст. аристократичний образ поляків ,закріпив” у ній, а водночас i засудив Іван Франко, переводячи етнопсихологічні особливості характеру сусідів у площину їхньої культурної й соціокультурної ідентичності. У шляхетних традиціях, на думку I. Франка, стверджувався ідеогенетичний тип усієї польської культури XIX ст. ${ }^{7}$ Ці традиції набували значення одного із структурних полюсів національно-релевантних уявлень про Польщу.

Однак якщо на початку XX ст. в художній літературі продовжує відтворюватися есенціалістичний підхід до поляків, заснований на переконанні про їхню аристократичність, то саме в критиці складаються в цей час інші ідентифікації, що свідчать не стільки про переоцінку існуючих поглядів, скільки про те, що вони наповнюються новим змістом. Окреслюється зміна векторної дії

${ }^{5}$ Див., наприклад: С. Вели чко, Сказання про війну козацьку з поляками..., [в:] Давня украйнська література, Хрестоматія, упоряд. М. М. Сулима, Київ 1995, с. 472-485.

6 Див.: Б. Гудь, Польсько-украӥнський етносоціальний антагонізм на Київщині, Волині i Поділлі XIX - початку XX століть у дзеркалі української історіографії, Warszawskie Zeszyty Ukrainoznawcze, pod red. Stefana Kozaka, Warszawa 2006, t. 21-22, s. 40.

${ }^{7}$ I. Фран ко, Інтернаціоналізм і націоналізм у сучасних літературах, [в:] його ж, Зібр. твоpiв, у 50 тт., Київ 1984, т. 31, с. 43, а також його ж: Влада землі в сучасному романі, [в:] його ж, Зібр. творів, у 50 тт., Київ 1984, т. 28, с. 176. 
у сприйнятті Польщі й поляків, що набуває нового характеру та іншої концептуальності, а разом із тим проступають інші риси польського іміджу.

Поступово актуалізуються ідеї націєтворчого характеру - центральні для більшості українських авторів початку ХХ ст. та 1910-х років. У публікаціях Миколи Свшана, Дмитра Донцова, Гната Хоткевича та інших авторів поняття нації й культури розглядаються як фундаментальні та взаємозалежні, важливого значення набуває чинник тривалості й міцності національних основ. 3 огляду на це, польська спільнота становила гідний для наслідування приклад. Її сприймали як сформовану й стійку націю із власною системою цінностей, і це стало приводом для формування позитивних уявлень про поляків, змінило наявні погляди на них; було окреслено нові принципи сприйняття Польщі, що стали актуальними для українського народу.

Таким чином, завдяки літературній критиці, послаблюється об'єктивована в художній літературі XIX ст. ментальна модель, що слугує основою ідентифікації поляків як шляхти, ,зверхників” щодо українства. 3 наявних у художній літературі імагологічних епістем „приятель” (у Т. Шевченка, П. Куліша), „ворог” (у Т. Шевченка), „сусід” у критиці помітно актуалізується остання. Пріоритетності набуває національний детермінізм поляків, і це насамперед зумовлює увагу до практики польського національного будівництва. Адже поняття національного характеру в розумінні багатьох українських науковців містила такі основоположні чинники, як внутрішня єдність суспільства та його уміння протиставляти себе згубним „чужим впливам”. Виступи критиків сигналізують, що на початку XX ст. стверджується діалогічна модель, що на противагу бінарній опозиції у XIX ст. (Свій / Чужий або Інший) взаємодіє 3 ,іншим”, навіть інтегрує ,іншого”, зберігаючи його відмінність, в ідентичність Я. Зустріч 3 „іншим” спонукає й до перебудови позицій, у яких „своє” існує лише стосовно „іншого”. Наприклад, з огляду на польський досвід, Дмитро Донцов закликав орієнтуватися на культурні цінності Свропи й Америки. „Пустий викрут, - звертався критик до своїх земляків, - ніби на дорозі стоїть русифікація з ії школою, що не дає знання західноєвропейських мов. Та сама русифікація є в королівстві польськім. А мимо того - правда, в силу історичної традиції - польська інтелігенція не стратила контакту з європейською культурою, що й помітно як на польській штуці, так і на літературі і публіцистиці", . Тут ідеться не лише про ствердження європейських коренів польської культури, а й про намагання показати, що колоніальний стан культури не обов'язково $є$ чинником іiї блокування. Виходом a posteriori зі стану залежності, а водночас протидією йому повинні бути прозахідні орієнтації українців. Вони ж можуть відтворювати й пропольський вектор. Пронаціональні й прозахідні позиції поляків, що стали певним "захистом” проти русифікації й понімеччення, оцінили, крім Д. Донцова, також і Леся Українка, Микола Євшан, Гнат Хоткевич та інші. Їхні твори нейтралізували та піддавали верифікації узвичаєний „шляхетський” образ Польщі.

Цінували солідарність поляків не лише супроти загрози ззовні, не менш значущою була їхня згуртованість у внутрішньому житті спільноти. Увагу акцентували на національно-ідейній єдності поколінь, від якої залежало не лише формування, а й збереження польської ідентичності. 3 цього приводу зазначалося, що в середовищі поляків „старі самі виховували своїх дітей

${ }^{8}$ В. Будн ий, Розгадка ирарів Ціриеї: начіональні образи та стереотипи в освітленні літературної етноімагології, [в:] „Слово і час”, 2007, № 3, с. 54.

9 Д. Донцов, 3 українського життя, [в:] „Дзвін”, 1913, кн. IV, с. 293. 
у напрямку поваги до своєї культури, національної гідності, нації, поважали їх і при всякій нагоді підтримували як матеріально, так і морально"10. У тогочасній ситуації, коли в українській періодиці точився ідеологічний конфлікт між „батьками” й „дітьми” - старим українським народництвом і адептами модернізму, - подібні голоси мали вельми актуальне звучання: містили докір на адресу українських „старих”, що не йшли шляхом своїх польських ровесників та, по суті, не відповідали вимогам нового часу. Але це був також і приклад того, як на платформі національного порозуміння слід будувати взаємини між поколіннями, приклад зв'язку поколінь, їхнього постійного діалогу, що ставало гарантією захисту базових національних цінностей з їх основним пріоритетом - свободою Польщі, а то й загалом її буттям.

Наголошувалося й на досягненнях сусідів стосовно мовного питання, що для українства завжди мало екзистенційну вагу, а внаслідок лібералізації прав національних меншин у Росії в 1905 році постало завдання прискореного унормування української літературної мови. Приклад польського народу, якому за умов політичного роз'єднання між трьома державами (Австро-Угорщиною, Німеччиною й Росією) вдалося не лише зберегти свою мову, а й виробити й запровадити необхідні норми, був для української інтелігенції зразком для наслідування. „Ми, звичайно, йшли і повинні йти в цьому ділі за приміром поляків - далеко свідоміших робітників на полі всенародного воскресіння. Не політичні границі на території, але етнографічні відмеження повинні обняти простір народного духовного життя" "1. Це голос в дискусії з мовного питання, що в 1907 році точилася на сторінках часопису „Україна”. Мова як важливий чинник національної самостійності включається в проблемне поле українського самоствердження: служить визначником етнічної, а не державно-політичної приналежності. Отже, усталеність і визначеність національних позицій поляків, дотримання спадковості культурних традицій, збереження й розвиток польської мови - усе це позитивні риси, які відповідно сприймало українство.

У проекції на українські реалії порівняння 3 ,іншим” повинно було вплинути на вироблення власних національних пріоритетів. Літературно-критичні й публіцистичні статті, автори яких аналізували суспільне життя поляків, мотивацію їхнього самозбереження в культурі, мали на меті вказати на слабкі аспекти українського націєтворення і тим самим по можливості вплинути на його перебіг. Отже, українські критики зауважили важливу імагологічну ознаку, коли власне внутрішні проблеми, насамперед ті, що стоять на „порядку денному", визначають ставлення до “іншого" (або, точніше, використання ,іншого”). Зустріч 3 ,іншим” спонукає до перебудови позицій, у яких „своє” існує стосовно „іншого" критиків за особливостями польського національно-культурного життя стали основою нових уявлень про поляків, а водночас вплинули й на створення раціональної моделі взаємосприйняття й співіснування, що відповідає кращим традиціям міжкультурного спілкування. Адже ,розвиток культури, як і акт творчої свідомості, є актом обміну й постійно має на увазі „іншого” — партнера у здійсненні цього акту"13.

${ }^{10}$ О. Ковалевський, Старі й молодi, [в:] „Українська хата”, 1914, № 1, с. 59.

${ }^{11}$ М.Пачовський, Літературна мова на Україна, [в:] „Україна”, 1907, т. 2, с. 62.

12 Див.: В. Будни й, Зазнач. прачя.

${ }^{13}$ Ю. Лотман, До побудови теорії взаємодії культур: семіотичний аспект, [в:] Сучасна літературна компаративістика: стратегії і методики, антологія, за ред. Д. Наливайка, Київ 2009, c. 205. 
Проте „у кожний конкретно-історичний момент, на будь-якому етапі історичного розвитку національне сприйняття інонаціонального феномену неоднозначне. ... Тут має місце різноплановість, різнорівневість, яка сягає такого ступеню, на якому нерідко втрачається будь-яка кореляція між тим, що відбувається навіть у межах сусідніх планів та рівнів" ${ }^{4}$. Справедливе зауваження, оскільки нація, як уважає Маріус-Франсуа Гюйяр, - надто складний когломерат; вона не редукується до відповідної простої єдності. Таким чином, складна конструкція, що формувалася в літературно-критичних поглядах на Польщу, позначена радикальністю, навіть полярністю сприйняття. Поряд із позитивним, що не має безпосереднього стосунку до України, наприклад справи польського національного будівництва, існують інвективи, що активізуються тоді, коли справа торкається польської рецепції України або коли йдеться про українсько-польські стосунки — той, за висловом Івана Франка, „гордійський вузол польсько-руського питання" 15 .

Для таких українських авторів, як Іван Франко, Микола Євшан, Михайло Лозинський характерним стає увага до загостреного „звучання” проблеми, окресленої намаганням розмежувати ідентитет і алтеритет, „власне” й „чуже”, увиразнити „своє” та відокремити його від сусіднього. За цими імагологічними категоріями, що сьогодні інтенсивно вивчає постструктуралістська культурологія, стоїть інша важлива для імагологічних структур складова - спроможність певного етносу захищати й коригувати свій імідж у сприйнятті інших народів. На позаминулому рубежі віків це трактувалося як здатність відстояти культурний суверенітет України, вивести його з тіні меншовартості, сформованої колоніальним статусом. Була репрезентована серйозна спроба культурного опору й активізації опозиції (Едвард Саїд), що здійснювалося через увиразнення ролі літератури у ствердженні домінуючої нації. Роль Польщі в цих стосунках подвійна — колонізованої країни й колонізатора. „Ніде ж бо не сказано, що колонізована спільнота не може виявляти колонізаторських рис"16.

Не даремно українські критики звертаються до польської романтичної і поромантичної літератури, знаходячи в ній джерело сили і стійкості міфічного мислення про Україну, стабільність і тривалість певних структур колективної свідомості, що вимагало переосмислення й розставлення інших акцентів.

Відтак увага українських авторів концентрується на представниках української школи в польській літературі, особливо на творчості Богдана Залеського як її основоположника, а також на романі Вогнем і мечем Генрика Сенкєвича, який, на думку сучасних дослідників, продовжує романтичну візію України ${ }^{17}$. Ця візія не є однолінійною, вона навіть має полярний характер: сентиментальноідилічна, ілюзорно-примарлива в романтиків та ксенологічна картина „диких полів" із варварським населенням у Г. Сєнкевича. Але така суперечливість простежується лише 3 першого погляду: насправді ж візії об'єднує міфологізоване уявлення про Україну ${ }^{18}$. Природно, що спільним лейтмотивом українських

${ }^{14}$ П. Рудяко в, Міфокомплекс Росії в сучасній українській соиіокультурній свідомості, [в:] Електронний ресурс: http://www.dc-summit.info/temy/nacionalnaja-identichnost/720-720.html (2010.07.11).

${ }^{15}$ I. Фран ко, Stanisław Zdziarski. Ze studyów nad „, szkołq ukraińska”, [в:] його ж, Зібр. творів, у 50 тт., Київ 1982, т. 33, с. 104.

${ }^{16}$ Б. Бакула, Креси без узаємних викреслювань, [в:] „Критика”, 2010, число 1-2, с. 17.

${ }^{17}$ D. Beauvois, Trójkąt ukraiński. Szlachta, carat i lud na Wołyniu, Podolu Kijowszczyźnie 17131914, przełożył K. Rutkowski. Lublin 2005, s. 12.

18 Цьому питанню присвячена грунтовна розвідка Г. Грабовича Грані міфічного: образ України в польському й украӥнському романтизмі, [в:] його ж, До історї̈ української літератури: дослідження, есе, полеміка, Київ 1997, с. 170-195. 
критичних студій $є$ намагання акцентувати увагу на „штучності” літературного образу Украни; простежується прагнення довести, що в обох випадках образ України постав усупереч історичним фактам, тому він такий неадекватний. Звідси виникає потреба виявити ідеологічну мотивацію польських митців, що й допоможе відстояти образ „свого” в очах „чужого”. Щоправда, українські автори ніде прямо не пропонують свій, справжній образ України, що демаскував би, деконструював тексти метрополії. Але, напевно, не було й такої потреби, оскільки статті I. Франка, М. Свшана, М. Лозинського призначалися українському читачеві, якому образ своєї країни був добре відомий. Позиція критиків репрезентує приклад протистояння колоніалізму. На думку Марка Павлишина, це опір колоніалізму, що виражається в намаганнях перевернути ієрархію колоніальних вартостей, і „на місце колонізаторських (,ффальшивих”) мітів поставити („правдиві”) міти національного визволення"19. У цьому разі українські автори, якщо безпосередньо й не репрезентували правдивий міф замість фальшивих, то, напевно, виокремлювався він у контексті їхніх статей.

На думку критиків, польські романтики своєрідно інтерпретували українську культуру (історичну минувшину, усну народну творчість, природну ауру тощо) як частину польської культури, іï регіонального різновиду. По суті, таке бачення репрезентує відповідне застосування „прийому культурного колоніалізму”, до якого належить і ,привласнення максимальної вартості метрополітальній культурі" ${ }^{20}$. Інтегральне сприйняття України й стало підгрунтям для міфічних уявлень, адже через посередництво художньої літератури воно впроваджувалося в колективну свідомість поляків і навіть спонукало їх до пошуків етнокультурної ідентичності, а то й загалом ставало базою самоіндефікації. Українські автори усвідомлювали важливе значення романтизму, що відзначалося інтенсивним процесом формування модерних націй. Це своєрідно відобразилося в тогочасній художній літературі. У першій половині ХІХ ст. художня література була виразником суспільних настроїв, тому проблема кристалізації національної свідомості ставала стрижневою у творчості багатьох письменників. 3 цих позицій оцінювали й польську романтичну поезію (I. Франко, М. Свшан, Леся Українка), що розцвіла в добу „політичного небуття” Польщі й перетворилася на ту силу, що репрезентувала націю, ії культурне, а не лише літературне тло в одній площині з європейським романтизмом. Водночас для української перспективи польський романтизм як потужне самоствердження „польськості” призводить до „втягування” української культурної сфери в іiї домінуючі структури, тому критика, оберігаючи свою культуру, захищає українську національну тотожність. Разом із тим, акцент на чиннику приналежності української культурної сфери українському народу увиразнює iii самостійність, що, як відомо, стало базою для формування самобутнього українського письменства.

Український світ, що підживлював почуття, думки й передусім уяву польських романтиків, забезпечував присутність у літературі однаковою мірою i „зверхника”, i підлеглого (польського пана, українського козака, парубка). Виникнення такої ситуації, коли одна велика дискурсивна система має гегемонію над іншою, на переконання критиків, і мотивувало створення міфу. Так, на думку I. Франка, романтичний міф, далекий від правди життя поневоленого українського народу, породжений ідеологічним контекстом з його основним гаслом — „Україна для Польщі”.

${ }^{19}$ М. Павлишин, Постколоніальна критика і теорія, [в:] Антологія світової літературнокритичної думки ХХ ст., за ред. М. Зубрицької, Львів 1996, с. 533.

${ }^{20}$ Там само. 
Польському поетові Б. Залеському властива „політична містика, котра хоче в Україні бачити підвалину історичної Польщі і таким способом являється продовженням шляхетських традицій ще від часу Люблінської унії, — отсе ті сили, котрими Залеський порушував польську суспільність" 21 . Ілюзорна, уявна, „мальована” та „декораційна” Україна складає необхідний елемент поетових містифікацій, мета яких — виключити „з української традиції все, що нагадувало (...) власновольну, самостійну, протестуючу Україну"22. Осмислення цього факту привело до створення в читацькій свідомості відповідного фіктивного образу України, що надалі став самостійним літературним явищем. Франкова раціональна оцінка стала противагою до ірраціонального й суб'єктивнопсихологічного усвідомлення України. Підриває вірогідність містифікацій Б. Залеського й підкреслена критиком постійна поетична розробка теми одвічної польсько-козацької єдності, що так само суперечить історичним фактам, а також подальші ідеї польського романтика, що накладаються на цю парадигмy, - католицький містицизм і месіанізм та навіть елементи шовінізму. I хоч на час виступу I. Франка — йдеться про відгук на смерть Б. Залеського 1886 р. романтичний міф про Україну перейшов у площину історії, проте в українців з'явилося профетичне відчуття, що цей міф може в будь-який момент відновити свою життєдайність (сьогодні прикладом слугує література, присвячена давнім кресам Речі Посполитої, через те вона нерідко не позбавлена подібного міфічного звучання ${ }^{23}$ ).

Продовжує лінію Івана Франка Микола Євшан. Він так само реалізує основну ідею - викрити закладену в творчості Б. Залеського тенденційність поглядів на інтегральне значення України для Польщі та культурну місію останньої. Тим самим критик засвідчує, що спротив міфологічному мисленню про Україну може виявити себе за будь-яких придатних для нього умов. У цьому разі простежуємо реакцію М. Євшана на книгу польського критика Юзефа Третяка Bohdan Zaleski. 1802-1831. Życie i poezja. Karta z dziejów romantyzmu polskiego, що з'явилася в 1912 році. У полеміці із польським критиком, який назвав поетів „української школи” третьою після політичної й релігійної „поетичною унією” в історії Речі Посполитої, М. Євшан зазначає: „Нехай вони будуть апостолами згоди і миру, але той мир - не що інше, тільки стремління до збільшення стану посідання мирною дорогою"24. Відтак, виступаючи проти полоноцентричного бачення України, М. Свшан указує на поверхневий характер „спілкування” Б. Залеського з українським світом: воно може „не зачіпати самого світогляду і не впливати на нього”, Україна в поезії „барда” - лише „кольористичне тло”, сформоване спогадами дитинства. Критик навіть пропонує розрізняти, як несумісні етнопсихологічні категорії, риси поетової вдачі - українофільство й польський патріотизм. Проте своєю розробкою української тематики Б. Залеський потрапив на гребінь романтичної хвилі, а привнесена ним у польську літературу тема України засвоюється польською спільнотою

${ }^{21}$ I. Фран ко, Юзеф Богдан Залеський, [в:] його ж, Зібр. творів, у 50 тт., Київ 1983, т. 27, с. 31.

22 Там само, с. 32.

${ }^{23}$ Аналітичний розгляд літературного масиву, в цетрі якого тематика так званих кресів, здійснив Богуслав Бакула; див. там само, с. 16-22, а також польськомовну публікацію цього автора: В. Bakuła, Kolonialne i postkolonialne aspekty polskiego dyskursu kresoznawczego (zarys problematyki), [w:] „Teksty drugie”, 2006, nr 6, s. 11-33.

${ }^{24}$ М. Євшан, Богдан Залеський $і$ Украйна, [в:] його ж, Критика. Літературознавство. Естетика, упоряд. Н. Шумило, Київ 1998, с. 327. 
„як збагачення природних скарбів національної, своєї культури”25. Поетична спадщина Б. Залеського, як це помітив М. Свшан, демонструвала злиття особистого, індивідуального з колективним, що фактично й перетворювало естетичне уявлення про Україну на міфічне та забезпечувало живучість міфу в польському суспільстві. Так було виявлено й піддано критиці складові міфотворчого механізму, за яким здійснювалася інтеріоризація українського світу й самого образу України всередину польської культури.

Для романтиків з їх ностальгією за втраченим раєм - Україною образ iii не мав негативного забарвлення (можливо, з причини включення іiі в систему координат своєї культури). 3 виходом у світ роману Б. Сєнкевича перспектива в літературі змінюється з сентиментальної на відверто ворожу. Україна існує в категоріях „чужого”, з яким був негативний контакт; коли „чуже” загрожує „своєму” (його стабільності, навіть свободі), ставлення до нього відверто негативне. Звичайно, й романтики, й Г. Сєнкевич надто активно репрезентують відповідні негативні емоції, що ускладнює об’єктивне сприйняття України. Однак в романі Вогнем і мечем ситуація небезпеки й загрози з боку „чужого” складає реальний, соціальний і соціокультурний контекст, в якому формується образ ворога. Останній виявляється ефективним засобом об'єднання людей перед можливою небезпекою, впливає на їхні умонастрої.

У символічному сенсі в романі, як відомо, присутні протилежні візії України й Польщі. Демонізуючи першу й сакралізуючи другу, твір спонукає до піднесення духу “польськості” в час занепаду Польщі після політичних розподілів її земель у XVIII ст. й остаточного іï зникнення з карти Свропи як самостійної держави. Г. Сєнкевич в умовах загрози розвитку національної свідомості поляків прагне, щоб література виконувала функцію патріотичного заохочення й пробудження нації, а така настанова реабілітувала романтичну концепцію історії, засновану не на документальних фактах, а на суб'єктивній тенденції, грі уяви ${ }^{26}$. Глибинний суспільний резонанс „сєнкевичівської мрії” підсумовує сьогодні польська дослідниця Марія Яніон: „Колонізовані в XIX столітті загарбниками, ми могли пишатися тим, що колись самі були колонізаторами"27.

Характерно, що в час виходу Вогнем і мечем і пізніше — в період інтенсивного розгортання його популярності в Польщі романістика як жанр літератури переживала в Свропі захід своєї слави. На зміну великим романам йшли малі прозові форми, що швидко здобували визнання (приміром, інтенсивно розвивалася новелістика). I той факт, що трилогія Г. Сєнкевича, частиною якої є Вогнем і мечем, піднесена була до рівня найбільш значущої духовно-національної цінності, свідчить про роль твору, аналогічну до класичної західноєвропейської романістики. Едвард Саїд у монографії Культура й імперіалізм стверджує, що саме роман забезпечив згоду суспільства на чужоземну експансію. Такі відомі романи, як Великі сподівання та Домбі і син Чарльза Діккенса, Ностромо та Серие темряви Джорджа Конрада, Кім Редьярда Кіплінга та інші Е. Саїд однозначно пов'язує з імперським експансивним процесом, „частиною якого вони демонстративно й неприховано були"28. До названих творів можна віднести й роман Г. Сєнкевича.

\footnotetext{
${ }^{25}$ Там само, с. 328.

26 Так слушно вважає Ярослав Поліщук у дослідженні: Icmорична тема в літературі як предмет полеміки: Гоголь - Куліш - Сенкевич - Cтарищький, Warszawskie Zeszyty Ukrainoznawcze, 2005, t. 19-20, s. 131-132.

${ }^{27}$ M. Janion, Niesamowita Słowiańszczyzna. Fantazmaty literackie, Kraków 2007, s. 170.

${ }^{28}$ Е. Саїд, Культура й імперіялізм, Київ 2007, с. 15.
} 
Українська реакція на твір Г. Сєнкевича пов'язана із запереченням негативних історичних стереотипів польського бачення України й українців, створених письменником. Попри те, що свого часу українські автори фактично не відреагували на факт публікації роману й не розгорнули відповідної полеміки, однак згодом вони почали висувати аргументи, що повинні були не лише спростувати польські уявлення про українців, а й вплинути на власне національне самоствердження.

Позаминула межа століть теж дає подібні приклади. Показовими тут є праці відомого львівського публіциста Михайла Лозинського до київської газети „Рада”, де він виражає власну позицію щодо захисту іміджу своєї батьківщини. Через викривальний пафос його праць - засудити Г. Сєнкевича як творця негативного стереотипу України - читачі вбачають у них ширший історикоі національно-літературний контекст. Названий автор демонструє наявність стійкого зв'язку між громадським інтересом до чужоземного іміджу своєї країни та процесом літературного осмислення цього іміджу й літературнокритичного впливу на нього. М. Лозинський здійснює спробу ідентифікувати авторські позиції, він усвідомлює ідеологічну спрямованість твору: романістика Г. Сєнкевича досягла своєї мети не лише тим, що однозначно заявила про польську рацію в історичній боротьбі XVII ст., а й виразно втілила суспільний настрій, що виник 3 комплексу колонізованого польського народу, який пережив тим більшу свою суспільну драму, чим сильніша була пам'ять про власне імперське минуле. Звідси прямолінійне нагадування публіциста українським читачам, що Г. Сєнкевич - це той письменник, "котрий „dla pokrzepienia serc” своїх родимців безкарно оплюгавлював і оклевечував великий народний рух української націі”"29. Викривальні наміри М. Лозинського здійснюються, так би мовити, перехресними стежками. Він намагається мінімізувати значення Г. Сєнкевича як видатного майстра слова й одночасно увиразнити національно значущу роль його роману, що вийшов далеко за межі простої лектури. Критик бачить співпрацю літератури й суспільства, якому відповідає міфологізація минулого настільки, що це суспільство не зауважує відмінностей між письменницькою уявою та історичними подіями. Вороже ставлення поляків до українців, зафіксоване в романі, має далекосяжні наслідки, оскільки твір відіграє велику виховну роль: він став „наче національним Євангелієм в польсько-українських справах, а в галицьких середніх школах його назначено для обов'язкового читання"зо. Ця сила має зворотний бік: якщо кожному новому поколінню поляків роман прищеплював позитивні національні якості, то до українців він пропагував однозначну зневагу: українці були тим негативним об'єктом, щодо якого й стверджувалися польські позитивні риси - патріотизм, шляхетність, а також прищеплювалось уявлення про цивілізаційну, культурну й релігійну місію поляків на схід від Варшави. Таке однозначне, отже, й тенденційне сприйняття України й українців стало характерною ознакою колективної свідомості поляків, перейшло до їхньої ментальності. А історична пам'ять виявлялася в політично-суспільному сенсі.

3 урахуванням ідеологічної спрямованості трилогії Г. Сєнкевич як автор багатопланових історичних полотен моделював відповідні художні прийоми. Оскільки авторське бачення історії, іiі суб'єктивне осмислення мало генетичний зв'язок із сучасністю, то, за переконаннями М. Лозинського, трилогія -

\footnotetext{
29 Див.: „Рада”, 1908, № 105, с. 2.

30 Там само, № 107, с. 2.
} 
це „не твори артиста, одушевленого ідеалом „правди істини і правди справедливості", тільки памфлети, писані в обороні панування польської шляхти над українським народом"з1. Г. Сєнкевич, отже, привертає увагу не сам по собі як письменник зі своїм художнім стилем чи самобутньою уявою, а як виразник певних суспільно-політичних ідеалів, що втілює мрію частини польського суспільства про панування на колишніх кресах Речі Посполитої, повернення Польщі ії колишньої державно-територіальної величі „,від моря до моря”. „,(...) Все, що змагає до одбудовання історичної Польщі, - пише М. Лозинський, - Сєнкевича вважає своїм генієм - ідеологом, пророком польського національного духу", тому й ,засудження Сєнкевича являється засудженням не особи, а цілого напрямку, який репрезентує серед польського громадянства Сєнкевич" 32 . Письменникові, як це помітив публіцист, судилося стати речником консервативно налаштованої частини польського суспільства, а його роману - бути засобом прищеплення цих настроїв своїм землякам. Отже, Г. Сєнкевич із більшою силою, ніж романтики, створює міф, основними складовими якого є почуття польської вищості на східних рубежах та виконання тут цивілізаційної й релігійної місії.

Праця публіциста демонструє так званий захисний націоналізм або контрдискурс; тим самим він утілює настрої українського суспільства, в яких прагнення рівноправних польсько-українських взаємин та паритетного сусідства зумовлювалися зміцненням почуття власної гідності як національного суб'єкта.

Проте на тлі подібних настроїв усе-таки мав місце „польський” образ України, що зазвичай активізує українські домагання свого бачення стану речей. Адже після Г. Сєнкевича польське колективне уявлення про Україну не може існувати без його візії. Трилогія, зокрема роман Вогнем і мечем, „переписала” у свідомості поляків романтичний образ України, репрезентувавши їі як нищівну анархічну загрозу для Польщі, в обороні якої постають небесні й земні сили на чолі із ренегатом Яремою Вишневецьким ${ }^{33}$.

Так, в рамках імагологічного дискурсу здійснюється ретроспективна ревізія українсько-польського діалогу. Звернення до польського романтизму і постромантичної доби актуалізували в українській критиці бінарну опозицію, що була особливо характерна для романтиків. Важливою ознакою романтизму $є$ превалювання суб'єктивної першості в моделюванні національних образів, які структурують „своє” й „чуже”; високоактивна роль при цьому належить першому інгредієнту ${ }^{34}$. Не важко помітити, що у статтях українських критиків функція „свого” в бінарній опозиції є подвійною. „Своє” існує як належне Польщі. Українські автори зауважили, що польська сторона вважає своїм українське. Окрім того, публікації, спрямовані на реформування українського іміджу в Польщі, попри їх незначну кількість і фрагментарність, усе ж не є випадковими, а становлять історично, культурно й психологічно обумовлену діалектичну єдність — „рецепцію-відповідь”. Вона сформувалась у просторі внутрішньої літературної полеміки, але мала значно ширший вимір - ідеологічний, етнокультурний, психологічний.

Отже, „рецепція-відповідь” має тенденцію до створення “нових правил комунікативного впливу”35. Образ України став не лише самостійним об’єктом

${ }^{31}$ Там само.

32 Там само.

${ }_{33}^{33}$ Г. Грабович, Зазнач. прачя, с. 188-189.

${ }_{34}$ Д. Наливайко, Зазнач. праия, с. 101.

35 Див.: В. Орехов, „Ответная” литературная рецепиия как объект илагологии, [в:] „Літературна компаративістика", Київ 2005, вип. I, с. 99. 
літератури: перебуваючи в просторі динамічного літературного явища й читацької свідомості, він відігравав подвійну роль. 3 одного боку, витлумачив і „переклав" український світ (навіть якщо його вважали локальним різновидом польського), тобто певною мірою сприяв порозумінню, з іншого, - спрощував, знімаючи все, що в нього не вкладалося, тобто породжував непорозуміння. Цей „Подвійний” образ, або образ-двійник (реальний і уявний) виявляв культурну активність і мав перспективу залишитися статичним, закріпленим в суспільній свідомості, тому критика через спроби його реконструкції, можливо, деякої трансформації змінює цей образ і тим самим відстоює позитивний імідж своєї країни, засвідчуючи дискурсивний опір проти колонізації.

Прикметно, що реакція українських критиків на польсько-українські взаємини має сьогодні своє продовження у двох головних виявах, що були заявлені на позаминулому порубіжжі. Це, по-перше, виразна орієнтація частини українських інтелектуалів (Оксани Пахльовської, Ліни Костенко, Оксани Забужко, Миколи Рябчука) на польський національний досвід як приклад націє- і державотворчих моделей сучасного українського суспільства. Другу лінію складають науково обгрунтовані, а водночас публіцистично-пристрасні засудження „мрій Сєнкевича про колонізацію інших”, що, на думку Марії Яніон, „витворили парадоксальну польську постколоніальну ментальність"з6.

Об'єктивно й переконливо звучать слова засудження зазначеного в працях польських дослідників Марії Яніон, Сжи Стемповського, Богуслава Бакули, французького полоніста Даніеля Бовуа. I в такий спосіб своєрідного взаємного перетину триває одвічний українсько-польський діалог, переносячи уявлення про „іншого” та самих себе в сучасну добу міжнародних інтеграційних культурних взаємин.

${ }^{36}$ M. Janion, Зазнач. праия, с. 12. 